\begin{tabular}{|c|c|c|c|c|c|}
\hline & Mansoura University \\
Faculty of Engineering \\
Mansoura Engineering Journal
\end{tabular}

\title{
Improving Voltage Stability of Doubly Fed Induction Generator - based Wind Farm using STATCOM

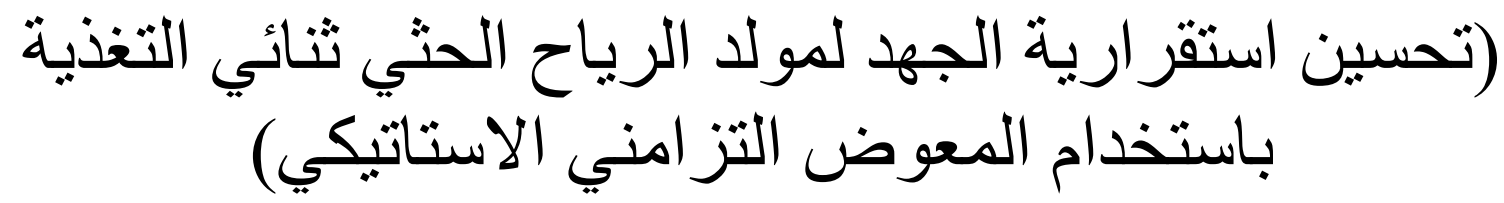

Iman F.Elzemeity Mohamed F. Kotb, Sahar S. Kaddah and Magdi El-Saadawi

\begin{abstract}
KEYWORDS:
DFIG, small signal stability, Eigenvalue, Voltage Stability, $P V$ curve, Reactive Power Compensation.
\end{abstract}

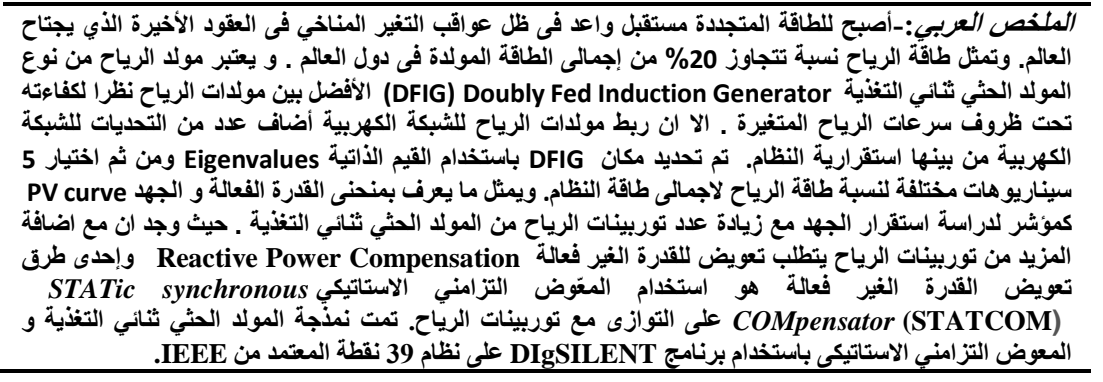

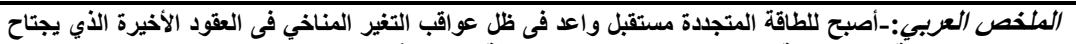

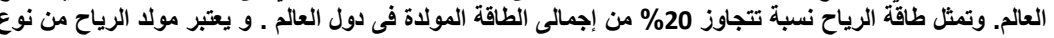

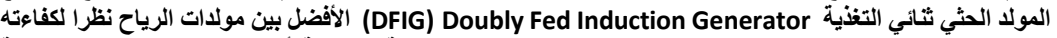

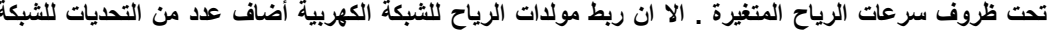

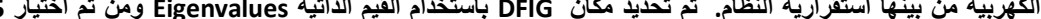

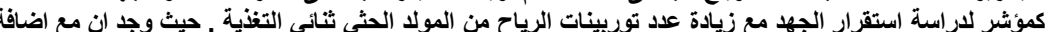

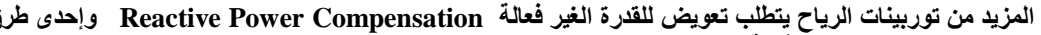

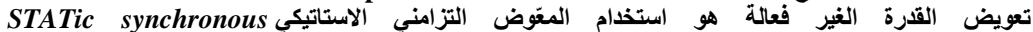

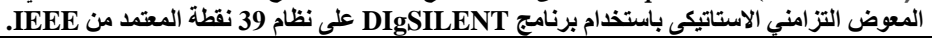

\begin{abstract}
Wind power is one of the most promising renewable resources and Doubly Fed Induction Generator (DFIG) is considered the most cost effective generator for connecting wind power to the grid as it has advantages over other types of wind generators such as operating under variable wind speeds, moderate size of power electronics, and complete control of active and reactive power. But it has consequences on the performance of power system especially power system stability. This paper states the influence of DFIG location on small signal stability using Eigenvalue analysis. Then, Evaluating PV Curve of critical bus as an indicator to state the impact of integrating wind power through DFIG on the voltage stability of power system under different Penetration levels. Besides approving the optimal Mvar for each penetration level to operate the system with wind power in a stable way using trial and error method. The proposed simulation is
\end{abstract}

Received: 21 April 2019 - Accepted: 12 June 2019

Iman F.Elzemeity, researcher at Mansoura university, faculty of Engineering Electrical Engineering Department (e-mail: elzamiti7@gmail.com).

Mohamed F. Kotb, lecturer at Mansoura university, faculty of Engineering Electrical Engineering Department (e-mail: mohamadfawzi@gmail.com). tested on IEEE 39 bus test system using DIgSILENT PowerFactory software with five penetration levels of DFIG to examine: $4 \%, 12 \%, 21 \%, 31 \%$ and $41 \%$.

\section{INTRODUCTION}

$\mathrm{D}$ OUBLY Fed Induction Generator (DFIG) is presented as the most cost effective wind generator. Adding DFIG to the grid has brought new challenges, one of them is the impact on power system stability. Power system stability has four main categories: voltage stability, frequency stability, rotor angle stability and transient stability. Voltage stability plays an essential issue to determine the maximum penetration level of wind to operate system safely.

Sahar S. Kaddah, Head of Electrical Engineering Department, faculty of Engineering at Mansoura university (e-mail: skaddah@mans.edu.eg).

Magdi El-Saadawi, professor at Mansoura university, faculty of Engineering Electrical Engineering Department (e-mail: m_saadawi@mans.edu.eg). 
Introducing steady-state model and dynamic model for different technologies of wind turbines has been introduced in [1] and from this studding the influence on voltage stability using PV curve and QV curve. Then using PWM converter to regulate reactive power capability in order to maintain voltage stability limits. In reference [2], sensitivity index is used as an indicator of voltage stability for Doubly-Fed Induction Generators (DFIG) and Fix Speed Induction Generator (FSIG) and comparing the voltage profile for the two different technologies.

Dynamic voltage stability is introduced under different penetration levels of wind energy [3]. After replacing DFIG based wind generators with synchronous generators, the voltage profile changes for the worst case and from this determining the maximum penetration level of wind turbines. Reference [4] states the impact of integrating DFIG on long term of voltage stability based on power capability curve of wind turbine using wind speed and terminal voltage as variables, then estimating the operational limits of DFIG to maintain within voltage stability margin. Where reference [5] studies the impact of DFIG on voltage stability using PSCAD to build the model of DFIG and back-to-back dual PWM inverter for control. The results show that voltage stability decreases with increasing in the numbers of wind turbines and the more the fault distance, the more the increase in voltage stability. It also states that Constant voltage control mode is better than constant power factor control mode for enhancing voltage stability. Reference [6] uses voltage deviation at Critical bus bars as an important index for study voltage stability after integrating wind turbines and under different loading conditions, where reference [7] focuses on the impact of Grid Side Converter (GSC) and Rotor Side Converter on the voltage stability of Point of Common Coupling (PCC). Reference [8] compares Active Power/ Voltage (PV curve) characteristics curve between DFIG and synchronous generator. It also suggests rotor voltage control to regulate the voltage of the system.

Existing of Under Load Tap Changer (ULTC), Generator Over-Excitation Limiter (OXL) in wind power system increases voltage instability [9], Rotor Side Converter (RSC) control method is presented as an effective method to prevent voltage collapse. There are two modes to regulate the voltage of the system: voltage control mode and power factor control mode [10]. Reference [11] introduces a simple method for voltage control by adding capacitor to Exciter Control System of DFIG. Flexible Alternating Current Transmission system (FACTS) such as STATic synchronous COMpensators (STATCOMs) and Static Var Compensators (SVCs) have been used as reactive power compensations to enhance voltage stability [12][13][14]. In Reference [15], the authors compare the voltage profile in case of using STATic synchronous COMpensators (STATCOMs) and Static Synchronous Series Compensator (SSSC), the results show that STATCOM has better influence on enhancing voltage stability.

References [16], [17] and [18] state that STATCOM can adapt with voltage fluctuations due to change of output power of DFIG and variations of wind speed. It enhances the voltage profile of all buses.
This paper introduces a model for STATCOM controller for improving voltage stability of wind power systems, which is installed at the Point of Common Coupling (PCC) of DFIG. Using DIgSILENT PowerFactory software and the simulation is based on IEEE 39-bus system as test system. Estimating PV curve under different penetration level to evaluates the required Mvar of STATCOM for each penetration level.

This paper is organized as follows. In section 2, Problem Formulation. In section 3, the Proposed Algorithm is described in details. Section 4 illustrates IEEE 39-bus system. In section 5 , the modeling of STATCOM Controller is described. Section 6 explains the simulation and the results which define the Mvar to install for each penetration level. The conclusion is given in section 7 .

\section{PROBLEM FORMULATION}

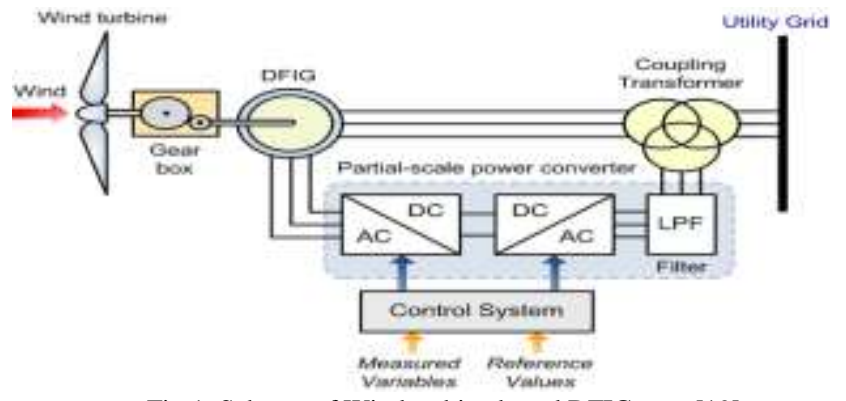

Fig.1. Scheme of Wind turbine based DFIG type [19]

DFIG is commonly used as it has the maximum efficiency under different wind speeds over other wind turbine generators as it adds a new challenge to the power system as it is designed to work $30 \%$ above and under its synchronous speed. DFIG is a wound rotor type, the stator side is connected to the grid through AC/DC/AC PWM converter and the rotor side is connected to the mechanical part of the wind turbine. The vector control is used to control flow of active power and reactive power between the stator and the grid as shown in Fig. 1.

The DFIG mathematical modelling as described in $\mathrm{d}-\mathrm{q}$ frame [21] as following fellow and as shown in Fig. 2:

$V_{d s}=R_{s} I_{d s}+\frac{d}{d t}\left(\Psi_{d s}\right)-\omega_{e} \Psi_{q s}$

$V_{q s}=R_{s} I_{q s}+\frac{d}{d t}\left(\Psi_{q s}\right)+\omega_{e} \Psi_{d s}$

$V_{d r}=R_{r} I_{d r}+\frac{d}{d t}\left(\Psi_{d r}\right)-\left(\omega_{e}-\omega_{r}\right) \Psi_{q r}$

$V_{q r}=R_{r} I_{q r}+\frac{d}{d t}\left(\Psi_{q r}\right)-\left(\omega_{e}-\omega_{r}\right) \Psi_{d r}$

The stator flux linkages:

$\Psi_{d s}=L_{s} I_{d s}+\mathrm{L}_{m} \mathrm{I}_{d r}$

$\Psi_{q s}=L_{s} I_{q s}+\mathrm{L}_{m} \mathrm{I}_{q r}$

The rotor flux linkages:

$\Psi_{d r}=L_{s} I_{d s}+\mathrm{L}_{m} \mathrm{I}_{d s}$

$\Psi_{q r}=L_{r} I_{q r}+\mathrm{L}_{m} \mathrm{I}_{q s}$ 
The generated torque:

$T_{e}+T_{\text {turbine }}=J \frac{d}{d t} \omega_{m}+B \omega_{m}$

Where: $\mathrm{Te}=$ Electromagnetic torque, $\mathrm{J}=$ Inertia of rotor , $\omega \mathrm{m}=$ Mechanical speed.

DFIG electromagnetic torque:

$T_{e}=\frac{3}{2} \frac{P}{2} L_{m}\left(I_{q s} I_{d r}-I_{d s} I_{q r}\right)$

DFIG active power and reactive power:

$P=V_{d s} I_{d s}+V_{d s} I_{q s}$

$Q=V_{q s} I_{d s}-V_{d s} I_{q s}$
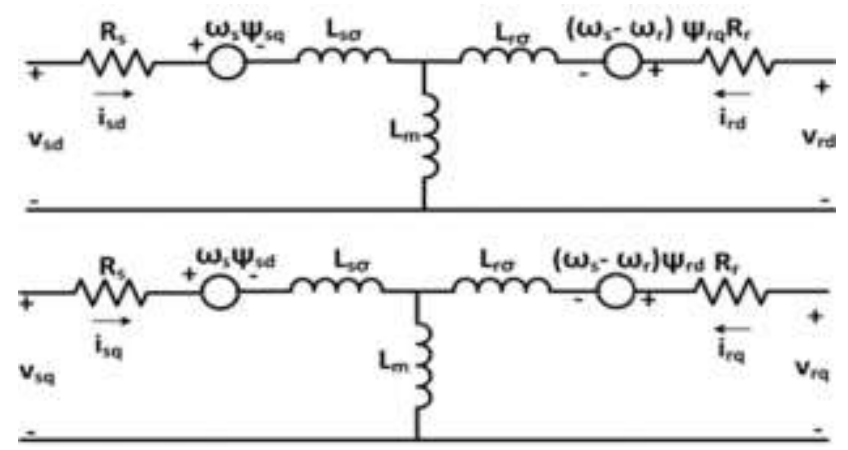

Fig.2. Equivalent circuit of DFIG in the d-q axis reference [20]

DFIG can operate around $\pm 30 \%$ the synchronous speed which causes fluctuations in output power represented in what is called Power/Wind speed characteristics curve as shown in Fig. 3[21]. There are three wind speeds to identify Power/Wind speed characteristics curve: Cut-in wind speed which is represented the minimum wind speed the DFIG can operate, Cut-out wind speed which is presented the maximum wind speed the DFIG can operate and the nominal wind speed in which DFIG reaches its maximum efficiency. As shown in Fig. 3 , there are four zones in Power/Wind speed characteristics curve. The first and the fourth zones are represented the zones in which DFIG cannot operate. Zone 2 represented the operation with maximum power coefficient Cpmax where Zone 3 , the DFIG generates its rated output power. The mathematical equations of wind turbine mechanical output are expressed by the following:

$\mathrm{P}_{\text {aero }}=0.5 \rho A \mathrm{C}_{\mathrm{p}} v^{3}$

$\mathrm{C}_{\mathrm{p}}=f(\lambda, \beta)=0.5\left(\frac{116}{\lambda_{\mathrm{i}}}-0.4 \beta-5 e^{-21 / \lambda_{\mathrm{i}}}\right)$

$\frac{1}{\lambda_{\mathrm{i}}}=1 /\left(\frac{1}{\lambda+0.8 \beta}-\frac{0.035}{\beta^{3}}\right)$

$\lambda=\frac{\mathrm{W}_{\mathrm{T}} R}{v}$

The aerodynamic torque: $\mathrm{P}_{\text {aero }}=0.5 \rho A \mathrm{C}_{\mathrm{p}} v^{3}$

Where: $\rho$ : the density of air $=1225 \mathrm{~kg} / \mathrm{m} 3, \mathrm{Cp}$ : the power coefficient, $v$ : the wind velocity $(\mathrm{m} / \mathrm{s}), \beta$ : the bitch angle, $\mathrm{R}$ : the radius of the turbine blades $(\mathrm{m}), \mathrm{A}$ : the cross section area of the WTG (m2), $\lambda$ : tip speed ratio, WT: the speed of wind turbine rotor $(\mathrm{rad} / \mathrm{s})$.

Due to the variations in output power of DFIG and stochastic wind speeds, the fluctuations of voltage profile increases with increase the sizing of wind generators in the system. In this paper, the locations of DFIG based on replacing the same MW of synchronous generator with DFIG. Sorting the possible locations in ascending order according to Electromechanical Oscillations which has a range of $0.2-2 \mathrm{~Hz}$ [22] using Eigen Value analysis. Eigen value consists of two parts: real part known as $\sigma$ and imaginary part. The more $\sigma$ is negative, the more the system is stable.

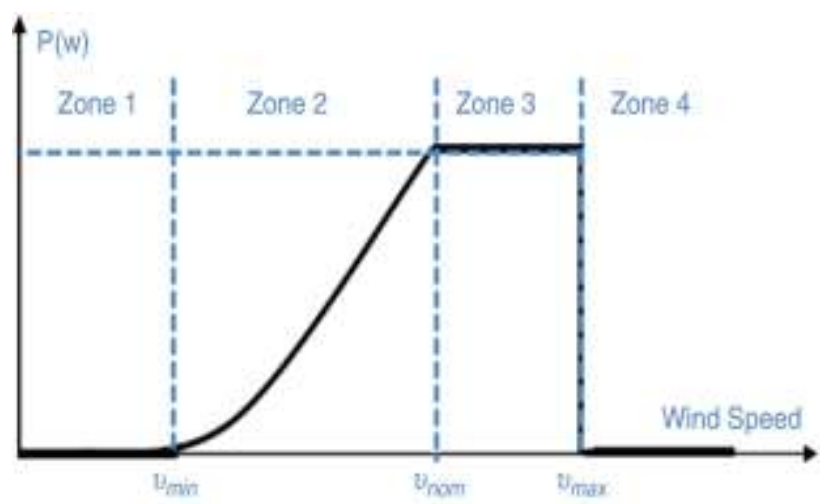

Fig.3. Wind turbine power characteristics curve [22]

\section{THE PROPOSED ALGORITHM}

The paper estimates the location of DFIG based on Eigenvalue analysis, then determines the available penetration levels at the predefined locations and studding the voltage profile of the critical bus of the test system which is defined as the weakest point in the system and the highest sensitivity to voltage fluctuations. To estimate voltage profile of critical bus, $\mathrm{PV}$ curve which is used to state the maximum MWs for the bus load to prevent voltage collapse and then evaluate if the system is stable or unstable as shown of Fig.4. Where $\mathrm{V}$ is the voltage of the critical bus and $\mathrm{P}$ is the total active power of the load. The aim of this paper is to evaluate the required Mvar of STATCOM as a reactive power compensation for different penetration levels of DFIG in order to improve voltage profile of the system.

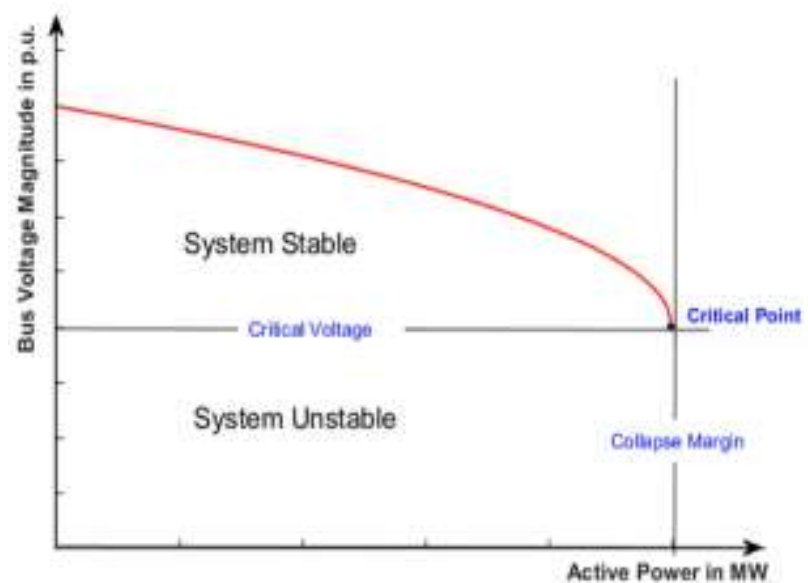

Fig.4. P-V curve of the critical bus to determine voltage stability 
There are seven steps for this proposed algorithm to be summarized as following:

Step 1: Build the test system without the presence of DFIG.

Step 2: State the permissible locations to install DFIG based on Electromechanical Oscillations results using Eigen Value method.

Step 3: Evaluate the penetration levels of wind generators depending on the predefined locations.

Step 4: Define the critical bus in the test system.

Step 5: Estimate PV curve of the critical bus under different penetration levels and define the MW Collapse margin for each case.

Step 6: Using STATCOM as a reactive power compensation to improve MW Collapse margin based on trial and error method.

Step 7: Compare the Mvar required for each penetration level to reach the MW Collapse margin of the original system.

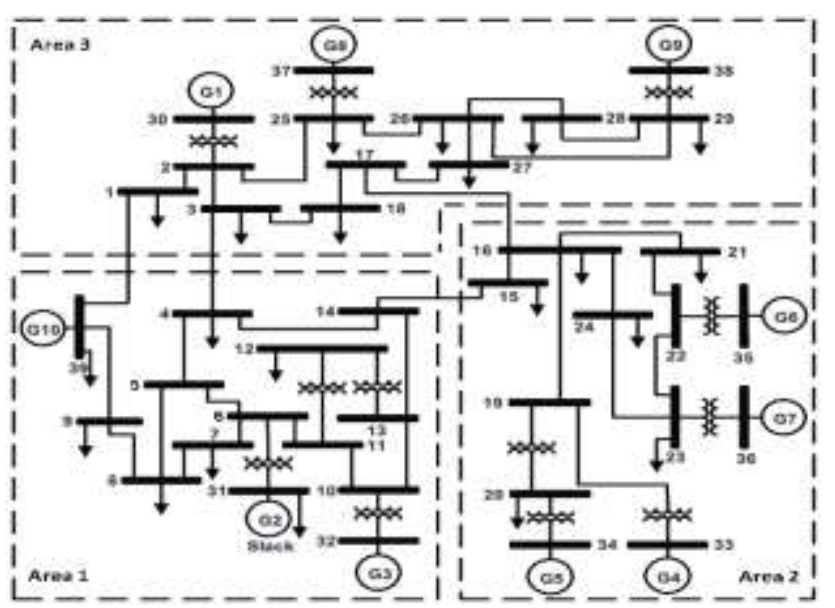

Fig. 5. New England test system [24]

\section{TEST SYSTEM DESCRIPTION}

IEEE 39 bus system which is known as New England Test System is consists of three areas and 10 Synchronous generators as shown in Fig.5 and Appendix A and is operating at $60 \mathrm{~Hz}$ [23]. "Gamesa G97 2 MW" is presented the type of DFIG which is used in this paper. The details of model are show in Appendix B.

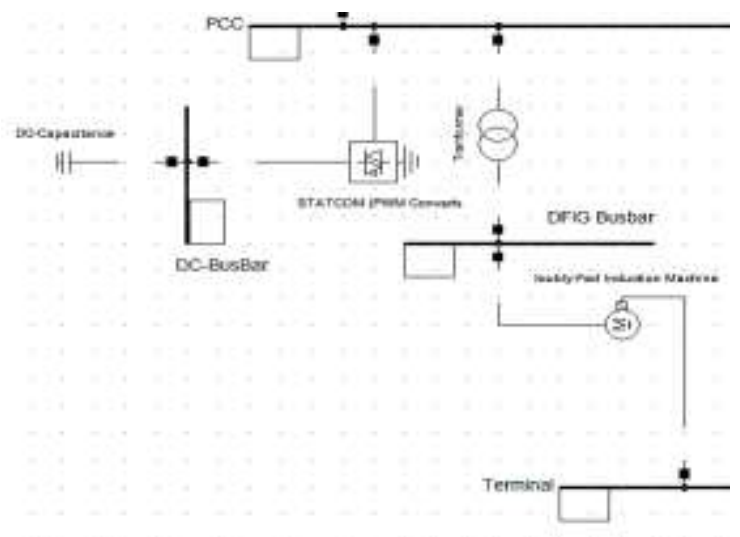

Fig. 6. STATCOM connection with DFIG at PCC point of DFIG

\section{STATCOM MODELING}

STATCOM, in this paper consists of series DC storage capacitance and pulse width modulation (PWM) which is connected to the point of common coupling (PCC) of DFIG as shown in Fig.6.

\section{SIMULATION AND RESULTS}

The Simulation has been carried out using DIgSILENT PowerFactory software in three stages: determine the locations and penetration levels of DFIGs, evaluate PV curve for each penetration level and compare it with the original test system and adding STATCOM to each DFIG at the point of PCC and from here estimating the Mvar required for each penetration level of DFIG.

\section{A. Determining Location and Penetration Levels of DFIG}

Location of wind farm has more factors than stability analysis. It can be onshore or offshore, for example offshore wind turbine requires between 10 to 30 meter for water height and Onshore wind energy requires identifying wind power class, cut-in speed and the average wind speeds should be above $8.5 \mathrm{~m} / \mathrm{s}$. The locations of DFIG based on replacing the same MW of synchronous generator with DFIG. Sorting the possible locations in ascending order according to Electromechanical Oscillations which has a range of $0.2-2 \mathrm{~Hz}$ using Eigen Value analysis. Eigen value consists of two parts: real part known as $\sigma$ and imaginary part. The more $\sigma$ is negative, the more the system is stable. By replacing the ten synchronous generators with DFIGs, replacing one at a time and define the $\sigma$ of the Eigen value for each replacing using $Q R / Q Z$ method in DIgSILENT. The results as shown in TABLE.I indicate that the best five locations with less electromechanical oscillations are by replacing the synchronous generators with DFIGs at buses $30,37,31,32$ and 36 respectively. And from the predefined locations for replacing synchronous generators with DFIGs, the five penetration levels of this paper are estimated as shown in TABLE.II

TABLE I

EIGEN VALUE ANALYSIS AFTER REPLACING SYNCHRONOUS GENERATORS WITH DFIGS AT THE TEN DIFFERENT LOCATIONS

\begin{tabular}{c||c}
\multicolumn{1}{c||}{ DFIG Location at Bus No } & Real Part $\boldsymbol{\sigma}_{\text {min }}$ \\
\hline Bus 30 & -0.35184644231 \\
\hline Bus 37 & -0.31141461947 \\
\hline Bus 31 & -0.30764785798 \\
\hline Bus 32 & -0.28324202251 \\
\hline Bus 36 & -0.28149419694 \\
\hline Bus 38 & -0.28080568898 \\
\hline Bus 35 & -0.27920623193 \\
\hline Bus 34 & -0.2780181199 \\
\hline Bus 33 & -0.25063543822
\end{tabular}


TABLE II

\begin{tabular}{|c|c|c|}
\hline \multicolumn{3}{|c|}{$\begin{array}{l}\text { MVAR REQUIRED FROM STATCOM FOR } 4 \%, 12 \% \text { AND } 21 \% \\
\text { PENETRATION LEVELS OF DFIG }\end{array}$} \\
\hline $\begin{array}{l}\text { DFIG Penetration } \\
\text { Level \% }\end{array}$ & $\begin{array}{l}\text { DFIG } \\
\text { Locations }\end{array}$ & Replacing MW \\
\hline $\begin{array}{l}\text { First Penetration } \\
\text { Level } 4 \%\end{array}$ & Bus 30 & $\begin{array}{l}\text { Replacing the } 250 \text { MW SG } \\
\text { at bus } 30 \text { with DFIG }\end{array}$ \\
\hline $\begin{array}{l}\text { Second Penetration } \\
\text { Level } 12 \%\end{array}$ & $\begin{array}{l}\text { Bus } 30 \\
\text { Bus } 37\end{array}$ & $\begin{array}{l}\text { Replacing the } 250 \mathrm{MW} \mathrm{SG} \\
\text { at bus } 30 \text { and the } 540 \mathrm{MW} \\
\text { SG at bus } 37 \text { with DFIGs }\end{array}$ \\
\hline $\begin{array}{l}\text { Third Penetration } \\
\text { Level } \\
21 \%\end{array}$ & $\begin{array}{l}\text { Bus } 30 \\
\text { Bus } 37 \\
\text { Bus } 31\end{array}$ & $\begin{array}{l}\text { Replacing the } 250 \mathrm{MW} \mathrm{SG} \\
\text { at bus } 30 \text {, the } 540 \mathrm{MW} \mathrm{SG} \\
\text { at bus } 37 \text { and the } 520 \mathrm{MW} \\
\text { SG at bus } 31 \text { by DFIGs }\end{array}$ \\
\hline $\begin{array}{l}\text { Fourth Penetration } \\
\text { Level } \\
31 \%\end{array}$ & $\begin{array}{l}\text { Bus } 30 \\
\text { Bus } 37 \\
\text { Bus } 31 \\
\text { Bus } 32\end{array}$ & $\begin{array}{l}\text { Replacing the } 250 \mathrm{MW} \mathrm{SG} \\
\text { at bus } 30 \text {, the } 540 \mathrm{MW} \text { SG } \\
\text { at bus } 37 \text {, the } 520 \mathrm{MW} \text { SG } \\
\text { at bus } 31 \text { and the } 650 \mathrm{MW} \\
\text { SG at bus } 32 \text { by DFIGs }\end{array}$ \\
\hline $\begin{array}{l}\text { Fifth Penetration } \\
\text { Level } \\
41 \%\end{array}$ & $\begin{array}{l}\text { Bus } 30 \\
\text { Bus } 37 \\
\text { Bus } 31 \\
\text { Bus } 32 \\
\text { Bus } 36\end{array}$ & $\begin{array}{l}\text { Replacing the } 250 \mathrm{MW} \mathrm{SG} \\
\text { at bus } 30 \text {, the } 540 \mathrm{MW} \text { SG } \\
\text { at bus } 37 \text {, the } 520 \mathrm{MW} \mathrm{SG} \\
\text { at bus } 31 \text {, the } 650 \mathrm{MW} \text { SG } \\
\text { at bus } 32 \text { and the } 560 \mathrm{MW} \\
\text { SG at bus } 36 \text { by DFIGs }\end{array}$ \\
\hline
\end{tabular}

B. Evaluating PV Curve for Each Penetration Level of DFIG

PV curve is evaluated using DIgSILENT PowerFactory software at the critical bus of the test system as shown in TABLE.III. The critical bus in IEEE 39 Bus system is bus 12 [26].The results show that the system is slightly influenced by increasing the penetration levels $4 \%$ and $12 \%$, but in case of $21 \%$ the collapse margin reduces $14.3 \%$ from its original value and for high penetration levels $31 \%$ and $41 \%$ of DFIG, collapse margin decreases by $61 \%$ and $64 \%$ respectively.

TABLE III

COLLAPSE MARGIN FOR $4 \%, 12 \%, 21 \%, 31 \%$ AND $41 \%$ PENETRATION LEVELS OF DFIG

\begin{tabular}{l||l}
$\begin{array}{l}\text { Penetration Level of } \\
\text { DFIG } \quad \%\end{array}$ & $\begin{array}{c}\text { Collapse Margin } \\
\text { (MW) }\end{array}$ \\
\hline Original System & 68.795249 \\
\hline $4 \%$ & 68.267248 \\
\hline $12 \%$ & 59.903251 \\
\hline $21 \%$ & 28.055250 \\
\hline $31 \%$ & 25.955250 \\
\hline $41 \%$ & 68.795249
\end{tabular}

C. Estimating the required Mvar for Each Penetration Level of DFIG

Using trial and error method for $4 \%, 12 \%, 21 \%, 31 \%$ and $41 \%$ penetration levels of DFIG to calculate the required Mvar of STATCOM compensation to restore the voltage stability margin to reach $69 \mathrm{MW}$ collapse margin as in the original system. The results show that as in TABLE.IV, the Mvar required for $4 \%, 12 \%, 21 \%, 31 \%$ and $41 \%$ penetration levels of DFIG are 185 Mvar, 234 Mvar, 738.7 Mvar, 1417 Mvar and 1498 Mvar respectively. The STATCOM is connected to the PCC point of the DFIG.
TABLE IV

MVAR REQUIRED FROM STATCOM FOR $4 \%, 12 \%, 21 \%$, $31 \%$ AND $41 \%$ PENETRATION LEVELS OF DFIG

\begin{tabular}{l||cc}
$\begin{array}{c}\text { Penetration } \\
\text { Level of DFIG } \\
\%\end{array}$ & \multicolumn{2}{c}{ Collapse Margin (MW) } \\
\hline $4 \%$ & 185 Mvar at DFIG at Bus 30 \\
\hline $12 \%$ & 185 Mvar at DFIG at Bus 30 \\
& 49 Mvar at DFIG at Bus 37 \\
\hline $21 \%$ & 185 Mvar at DFIG at Bus 30 \\
& 49 Mvar at DFIG at Bus 37 \\
& 504.7 Mvar at DFIG at Bus 31 \\
\hline $31 \%$ & 185 Mvar at DFIG at Bus 30 \\
& $49 \quad$ Mvar at DFIG at Bus 37 \\
& 504.7 Mvar at DFIG at Bus 31 \\
& 678.3 Mvar at DFIG at Bus 32 \\
\hline $41 \%$ & 185 & Mvar at DFIG at Bus 30 \\
& 49 & Mvar at DFIG at Bus 37 \\
& 504.7 Mvar at DFIG at Bus 31 \\
& 678.3 Mvar at DFIG at Bus 32 \\
& $81 \quad$ Mvar at DFIG at Bus 36
\end{tabular}

\section{CONCLUSION}

In this paper, the locations of DFIGs has been determined based on Eigenvalue analysis and from this inducing five penetration levels of DFIG to examine which are $4 \%, 12 \%$, $21 \%, 31 \%$ and $41 \%$. Using PV curve as an indicator of voltage stability at the critical bus of the test system which is bus 12 in IEEE 39 bus system, then determine the MW Collapse margin for each penetration level of DFIG. The results show that the system is slightly influenced by the increasing in penetration levels $4 \%$ and $12 \%$, but in case of $21 \%$ the collapse margin reduces $14.3 \%$ from its original value and for high penetration levels $31 \%$ and $41 \%$ of DFIG, collapse margin decreases by $61 \%$ and $64 \%$ respectively. The Mvar required from STATCOM compensation for different penetration levels of DFIG has been evaluated and tested on IEEE 39 Bus system. The methodology of evaluating the Mvar required for each penetration level in order to reach the MW Collapse margin of the original system before integrating DFIG to the grid is based on trial and error method. The results show that the Mvar required for $4 \%, 12 \%, 21 \%, 31 \%$ and $41 \%$ penetration levels of DFIG are 185 Mvar, 234 Mvar, 738.7 Mvar, 1417 Mvar and 1498 Mvar respectively. Simulation has been carried out using DIgSILENT PowerFactory software.

\section{Appendices}

APPENDIX B DATA OF GAMESA G97 2 MW

\begin{tabular}{l||l}
\multicolumn{1}{c}{\begin{tabular}{c}
\multicolumn{2}{c}{ Data Sheet } \\
\end{tabular}} & \multicolumn{1}{c}{ Value } \\
\hline Rated power & $2,000.0 \mathrm{~kW}$ \\
\hline Cut-in wind speed & $3.0 \mathrm{~m} / \mathrm{s}$ \\
\hline Rated wind speed & $11.0 \mathrm{~m} / \mathrm{s}$ \\
\hline Cut-out wind speed & $25.0 \mathrm{~m} / \mathrm{s}$
\end{tabular}




\section{REFERENCES}

[1] Y. Chi, Y. Liu, W. Wang and H. Dai.(2006).Voltage Stability Analysis of Wind Farm Integration into Transmission Network. International Conference on Power System Technology. Chongqing. pp. 1-7. Available: https://ieeexplore.ieee.org/document/4115920/

[2] M. Wang and C. Qiu. (2014). Probabilistic voltage stability analysis of wind farm integrated power grid. 7th International Conference on Information and Automation for Sustainability. Colombo. pp. 1-7. Available: https://ieeexplore.iee.org/document/7069568

[3] Z. Mi, H. Tian, Y. Yu, X. Su, X. Fan and J. Feng.(2009). Study on voltage stability of power grid with large scale wind farm interconnected. 2009 International Conference on Sustainable Power Generation and Supply. Nanjing. pp. 1-6. Available: https://ieeexplore.ieee.org/document/5348136/

[4] Londero, R., Affonso, C. and Vieira, J. (2017). Effects of operational limits of DFIG wind turbines on long-term voltage stability studies. Electric Power Systems Research. 142. pp.134-140. Available: https://www.sciencedirect.com/science/article/abs/pii/S03787796163 $\underline{03571}$

[5] Z. D. Wu, P. Dong and Y. C. Chen. (2017). Influence on voltage stability of wind power connected to the grid. 2017 7th International Conference on Power Electronics Systems and Applications - Smart Mobility. Power Transfer \& Security (PESA). Hong Kong. 2017. pp. 1-5. Available: https://ieeexplore.ieee.org/document/8277776/

[6] R. Panda, P. K. Sahoo, P. K. Satpathy and S. Paul. (2014). Impact analysis of wind power integration in existing power systems for study of voltage stability conditions. 2014 Eighteenth National Power Systems Conference (NPSC). Guwahati. pp. 1-6. Available: https://ieeexplore.iee. $.0 \mathrm{rg} /$ document/7103808/

[7] M. Mao, J. Hu and L. Chang. (2017).Voltage stability analysis on wind generation system from current control time-scale. 2017 Chinese Automation Congress (CAC). Jinan. pp. 7010-7015. Available: https://ieeexplore.ieee.org/document/8244041

[8] C. Lin, J. N. Jiang, C. Y. Tang and T. Runolfsson. (2011). A study on the impact of control on PV curve associated with doubly fed induction generators. 2011 IEEE/PES Power Systems Conference and Exposition. Phoenix. AZ. pp. 1-7. Available: https://ieeexplore.ieee.org/document/5772583

[9] S. Konar and D. Chatterjee, "Voltage Collapse Prevention in Doubly Fed Induction Generator Based Wind Farm Connected Power System", INAE Letters, vol. 1, no. 2, pp. 41-46, 2016. Available: https://link.springer.com/article/10.1007/s41403-016-0008-2

[10]R. R. Londero, C. M. Affonso, J. P. A. Vieira and U. H. Bezerra. (2012). Impact of different DFIG wind turbines control modes on longterm voltage stability. 2012 3rd IEEE PES Innovative Smart Grid Technologies Europe (ISGT Europe). Berlin. pp. 1-7. Available: https://ieeexplore.ieee.org/document/6465694

[11]D. Datta and M. R. I. Sheikh. (2014). Voltage stability augmentation of ig based wind farm using capacitor with exciter control system. 8th International Conference on Electrical and Computer Engineering. Dhaka. pp. 591-594. Available: https://ieeexplore.ieee.org/document/7026915

[12]K. Heetun, S. Abdel Aleem and A. Zobaa. (2015). Voltage stability analysis of grid-connected wind farms with FACTS: Static and dynamic analysis. Energy and Policy Research. vol. 3, no. 1, pp. 1-12. Available:https://www.tandfonline.com/doi/full/10.1080/23317000.2 015.1128369

[13] J. Tian, C. Su and Z. Chen. (2013). Reactive power capability of the wind turbine with Doubly Fed Induction Generator. IECON 2013 39th Annual Conference of the IEEE Industrial Electronics Society. Vienna. 5p. 5312-5317. Available: https://ieeexplore.ieee.org/document/6699999

[14]R. Manuela Monteiro Pereira, C. Manuel Machado Ferreira and F. Maciel Barbosa. (2014, March). Comparative study of STATCOM and
SVC performance on Dynamic Voltage Collapse of an Electric Power System with Wind Generation. In IEEE Latin America Transactions, vol. 12. No. 2. pp. 138-145. Available: https://ieeexplore.ieee.org/document/6749530

[15]K. R. Hridya, V. Mini, R. Visakhan and A. A. Kurian. (2015). Comparative study of voltage stability enhancement of a grid and loss reduction using STATCOM and SSSC. 2015 International Conference on Power, Instrumentation. Control and Computing (PICC). Thrissur. pp. 1-4. Available: https://ieeexplore.ieee.org/document/7455757

[16]Xu Baoliang, He Jinghan and Wang Xiaojun. (2012).Study of improving the voltage stability of wind farm by utilizing STATCOM based on RTDS. IEEE PES Innovative Smart Grid Technologies. Tianjin. pp. 1-6. Available: https://ieeexplore.ieee.org/document/6303185

[17]M. R. I. Sheikh, M. S. Hossain and R. Hossain. (2015).Stability enhancement of a grid connected wind farm by using STATCOM. 2015 International Conference on Electrical \& Electronic Engineering (ICEEE). Rajshahi. pp. 81-84. Available: https://ieeexplore.ieee.org/document/7428298/

[18]L. Shengqing, X. Wenxiang, L. Weizhou and Z. Huanyue. (2013). Wind Farm Grid Voltage Stability Researching Based on Cascade STATCOM. 2013 Third International Conference on Intelligent System Design and Engineering Applications, Hong Kong. pp. 16101613. Available: https://ieexplore.iee.org/document/6455183/

[19]I. Saki, "Active Power Control of Grid Connected DFIG 15 Wind with Energy System," [online] Available at: https://www.mathworks.com/matlabcentral/fileexchange/57590active-power-control-of-grid-connected-dfig-15-wind-with-energysystem-by-indraneel-saki. [Accessed at Jan. 2018].

[20] P. Swagat, P. Manas and K.P Tapan. (2014, March). A Stator Flux Oriented Vector Control Scheme for Decoupled Control of DFIG for Wind Energy Applications, 2014 International Conference on Innovations in Engineering and Technology (ICIET'14). Tamil Nadu. India. Vol. 3.no. 3 Available: http://www.rroij.com/open-access/astator-flux-oriented-vector-control-scheme-fordecoupled-control-ofdfig-for-wind-energyapplications.php?aid=49815

[21] Ihedrane Y., Bekkali C.E., Bossoufi B., Bouderbala M. "Control of Power of a DFIG Generator with MPPT Technique for Wind Turbines Variable Speed," Modeling, Identification and Control Methods in Renewable Energy Systems. Green Energy and Technology. Springer, Singapore, 2019, pp. 105-129. Available https://link.springer.com/chapter/10.1007/978-981-13-1945-7 5

[22] H. R. Iswadi, D. J. Morrow and R. J. Best. (2014, Sept). Small Signal Stability Performance of Power System during High Penetration of Wind Generation. The 49th International Universities Power Engineering Conference (UPEC). Cluj-Napoca. pp. 1-6. Available: https://ieeexplore.ieee.org/document/6934766

[23] DIgSILENT PowerFactory2017: Technical Reference Documentation, "39 Bus New England System," Germany, 2017.

[24] T. Fernando, K. Emami, S. Yu, H. Iu and K. Wong. (2016). A Novel Quasi-Decentralized Functional Observer Approach to LFC of Interconnected Power Systems. IEEE Transactions on Power Systems, vol. 31. no. 4. pp. 3139-3151. Available: https://ieeexplore.ieee.org/document/7283669/

[25] "Gamesa G97-2 MW," [online] Available at: https://en.windturbine-models.com/turbines/764-gamesa-g97 [Accessed at April. 2016].

[26] D.J. Sobajic. (2013). Neural Network Computing for the Electric Power Industry (2013, June). Proceedings of the 1992 Inns Summer Workshop INNS Series of Texts. Monographs, and Proceedings Series. Psychology Press, pp. 83. 